\title{
SKRINING KEMAMPUAN PHONOLOGICAL AWARENESS ANAK PRA SEKOLAH
}

\author{
Arif Siswanto**1, Hafidz Triantoro Aji Pratomo $^{2}$ \\ Poltekkes Kemenkes Surakarta Jurusan Terapi Wicara
}

\begin{abstract}
Background: In the learning process at school, especially in pre-school education, phonological ability is the entrance for children in mastery of language. In Indonesia, research that focuses on phonological abilities in pre-school children is still very limited. This study aims to determine the profile of pre-school children's phonological awareness abilities. Methods: Participants were recruited from the Surakarta ABA Thoyibah Kindergarten with a total of 27 class $B$ children to participate in this study. Screening is given to participants. The screening results will reflect the profile of children's phonological awareness abilities. Results: There are five items that can be used to screen pre-school children's phonological awareness skills: rhyme, syllable blending, initial phoneme identification, medial phoneme identification, and final phoneme identification. The results of the internal validation analysis of phonological awareness subtest were as follows: rhyme 0.684, syllable blending 0.772, initial phoneme identification 0.880, medial phoneme identification 0.862, and final phoneme identification 0.735. Conclusion: The value of internal validity or the correlation between items in phonological awareness screening is good because all items correlated have a correlation with a low probability value.
\end{abstract}

Keywords: Phonological Awareness, Pre-school

\section{PENDAHULUAN}

Di Indonesia, riset yang fokus pada aspek fonologi anak pra-sekolah masih sangat terbatas sehingga tidak heran jika di Indonesia cukup sulit untuk menemukan data profil kemampuan fonologi anak pada kurun waktu tertentu, karena data yang ada sebagian besar dirancukan dengan kemampuan bahasa secara umum. Sebagai gambaran, prevalensi phonological disorders pada anak sudah didapatkan di negara lain. Topbaș (2006) melaporkan bahwa terdapat 70 anak berusia 4-8 tahun mengalami phonological disorders dari 665 anak yang diteliti di negara Turki. Dalam studi epidemiologi observasional, Longo, et al (2017) menemukan bahwa terdapat $22.9 \%$ dari 525 anak yang tercatat di medical record dari tahun 2002 hingga 2011 di bagian barat wilayah kota Sao Paulo Brazil mengalami phonological disorders. Di negara yang sama, Ceron, et al (2017) menemukan $15.26 \%$ atau 132 anak dari total 866 anak yang berumur 38.11 tahun di kota Santa Maria Brazil mengalami phonological disorders.

Dasar pertimbangan peneliti untuk menargetkan pada anak usia pra-sekolah adalah karena pada masa inilah kemampuan phonological awareness anak mengalami perkembangan yang pesat. Harrison \& McLeod (2010) menyatakan bahwa pada masa awal anak-anak proses perkembangan bahasa cukup pesat sehingga sangat perlu untuk ditingkatkan. 
Di sisi lain, intervensi yang terlambat atau tidak tertangani dengan baik akan mengakibatkan berbagai masalah yang berkaitan dengan permasalahan bahasa misalnya permasalahan sosial, psikis, dan belajar.

Dari uraian di atas dapat disimpulkan beberapa hal. Pertama, aspek fonologi merupakan komponen yang sangat penting dalam proses tumbuh kembang anak. Kedua, ketiadaan instrumen asesmen fonologi merupakan masalah yang harus segera diselesaikan dan sangat ditunggu oleh praktisi klinis terapis wicara. Ketiga, upaya deteksi dini menjadi kunci dalam program preventif dan habilitatif khususnya bidang bicara dan bahasa.

\section{METODE PENELITIAN}

Penelitian ini termasuk jenis penelitian kuantitatif. Rancangan penelitian ini adalah deskriptif kuantitatif dengan pendekatan cross sectional. Populasi penelitian ini adalah semua anak yang bersekolah di TK ABA Thoyibah Surakarta yang berlokasi di Kecamatan Banjarsari Kota Surakarta. Sampel penelitian diambil dengan metode. Simple Random Sampling dengan ukuran sampel penelitian sebesar 30 anak. Instrumen penelitian yang akan digunakan dalam penelitian ini adalah kuesioner dan tes phonological awareness. Sedangkan analisis data dilakukan dengan menggunakan analisis univariat.

HASIL PENELITIAN

Tabel 1. Distribusi Frekuensi Penelitian

\begin{tabular}{llrc}
\hline Variabel & Klasifikasi & N & Persen \\
\hline \multirow{2}{*}{ Jenis kelamin } & Laki-laki & 13 & 48.1 \\
& Perempuan & 14 & 51.9 \\
Kelas & B1 & 11 & 40.8 \\
& B2 & 8 & 29.6 \\
& B3 & 8 & 29.6
\end{tabular}

\begin{tabular}{|c|c|c|c|}
\hline \multirow{5}{*}{ Pendidikan Ibu } & Sekolah Dasar & 1 & 3.7 \\
\hline & SMP & 4 & 14.8 \\
\hline & SMA & 9 & 33.3 \\
\hline & Diploma & 4 & 14.8 \\
\hline & Sarjana & 9 & 33.3 \\
\hline \multirow{9}{*}{$\begin{array}{l}\text { Pekerjaan } \\
\text { Ibu }\end{array}$} & Buruh & 2 & 7.4 \\
\hline & Karyawan & 4 & 14.8 \\
\hline & Swasta & & \\
\hline & Wirausaha & 3 & 11.1 \\
\hline & PNS & 1 & 3.7 \\
\hline & Guru & 1 & 3.7 \\
\hline & Rumah & 15 & 55.6 \\
\hline & Tangga & & \\
\hline & Lainnya & 1 & 3.7 \\
\hline \multirow{5}{*}{$\begin{array}{l}\text { Pendidikan } \\
\text { Bapak }\end{array}$} & SMP & 2 & 7.4 \\
\hline & SMA & 15 & 55.6 \\
\hline & Diploma & 1 & 3.7 \\
\hline & Sarjana & 5 & 18.5 \\
\hline & Magister & 3 & 11.1 \\
\hline \multirow{7}{*}{$\begin{array}{l}\text { Pekerjaan } \\
\text { Bapak }\end{array}$} & Buruh & 5 & 18.5 \\
\hline & Karyawan & 8 & 29.5 \\
\hline & Swasta & & \\
\hline & Wirausaha & 9 & 33.3 \\
\hline & PNS & 2 & 7.4 \\
\hline & Guru & 1 & 3.7 \\
\hline & Lainnya & 1 & 3.7 \\
\hline
\end{tabular}

Korelasi antar subtes diketahui dari hasil uji korelasi antar subtes. Hasil uji normalitas dengan menggunakan uji Shapiro Wilk dapat dilihat pada tabel 2.

Tabel 2. Hasil Uji Normalitas Total

\begin{tabular}{|c|c|c|c|}
\hline Sub Tes & Sampel & $\begin{array}{c}\text { Nilai Uji } \\
\text { Shapiro } \\
\text { Wilk }\end{array}$ & Signifikansi \\
\hline Rhyme & 27 & 0.953 & 0.257 \\
\hline $\begin{array}{l}\text { Syllable } \\
\text { Blending }\end{array}$ & 27 & 0.692 & 0.000 \\
\hline $\begin{array}{l}\text { Initial Phoneme } \\
\text { Identification } \\
\text { Medial }\end{array}$ & 27 & 0.689 & 0.000 \\
\hline $\begin{array}{l}\text { Phoneme } \\
\text { Identification }\end{array}$ & 27 & 0.612 & 0.000 \\
\hline $\begin{array}{l}\text { Final Phoneme } \\
\text { Identification }\end{array}$ & 27 & 0.743 & 0.000 \\
\hline
\end{tabular}
menunjukkan bahwa korelasi antar subtes memiliki korelasi. Hal ini ditunjukkan dari keterkaitan antar subtes dengan melihat korelasi dengan skor total setiap subtes. 
Tabel 3. Hasil Analisis Validasi Internal

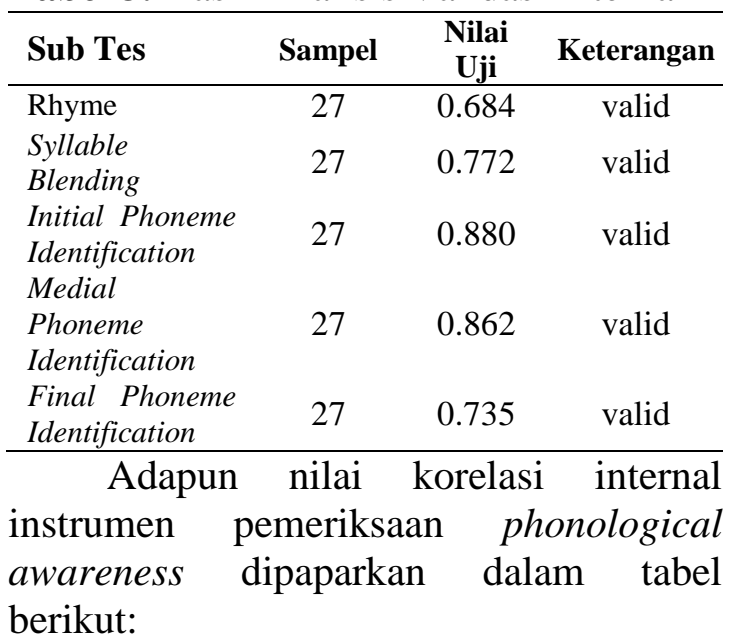

Tabel 4. Nilai Korelasi Internal Instrumen

\begin{tabular}{|c|c|c|c|c|}
\hline $\mathbf{R}$ & SB & IPI & MPI & FPI \\
\hline 0.953 & 0.362 & 0.590 & 0.454 & 0.491 \\
\hline$p=0.257$ & $\mathrm{p}=0.064)$ & $(\mathrm{p}=0.001)$ & $(\mathrm{p}=0.018)$ & $(\mathrm{p}=0.0$ \\
\hline SB $\begin{array}{c}0.362 \\
(p=0.064)\end{array}$ & $\begin{array}{c}\mathbf{0 . 6 9 2} \\
p=0.000)\end{array}$ & $\begin{array}{c}0.710 \\
\mathrm{p}=0.001)\end{array}$ & $\begin{array}{c}0.347 \\
(\mathrm{p}=0.077)\end{array}$ & $\begin{array}{c}0.742 \\
(\mathrm{p}=0.001)\end{array}$ \\
\hline IPI $\begin{array}{c}0.590 \\
(p=0.001)\end{array}$ & $\begin{array}{c}0.710 \\
\mathrm{p}=0.001)\end{array}$ & $\begin{array}{c}0.689 \\
p=0.000)\end{array}$ & $\begin{array}{c}0.656 \\
(\mathrm{p}=0.001)\end{array}$ & $\begin{array}{c}0.865 \\
(\mathrm{p}=0.001)\end{array}$ \\
\hline I $\begin{array}{c}0.454 \\
(p=0.018)\end{array}$ & $\begin{array}{c}0.347 \\
\mathrm{p}=0.077)\end{array}$ & $\begin{array}{c}0.656 \\
\mathrm{p}=0.001)\end{array}$ & $\begin{array}{r}0.612 \\
(p=0.00\end{array}$ & $\begin{array}{c}0.569 \\
(p=0.002)\end{array}$ \\
\hline $\begin{array}{c}0.491 \\
n=0.00\end{array}$ & 0.742 & 0.865 & 0.569 & 0.743 \\
\hline
\end{tabular}

Keterangan: $R:$ Rhyme, SB: Syllable Blending, IPI: Initial Phoneme Identification, Medial Phoneme Identification, FPI: Final Phoneme Identification

\section{PEMBAHASAN}

Kesalahan fonologi yang berdampak penegakan diagnosis gangguan bunyi bicara. Permasalahan fonologi dapat mengakibatkan anak memiliki permasalahan dalam kemampuan bahasa. Pennington (2009) menjelaskan korelasi antara kemampuan fonologi dengan pemahaman membaca (reading comprehension). Kemampuan pemahaman membaca dibangun dari kemampuan oleh kemampuan kelancaran membaca (reading fluency), kemampuan mendengar, dan kemampuan discourse. Kelancaran membaca disusun oleh kemampuan phonological coding dan orthographic coding. Phonological coding dipengaruhi oleh kemampuan phonemic awareness.

Phonological awaraness merupakan istilah digunakan secara luas untuk membahas tentang kemampuan untuk menganalisis struktur bahasa di mana phonemic awareness berhubungan dengan salah satu aspek phonological awareness yang secara langsung berhubungan dengan kemampuan manipulasi bunyi (Schuele \& Boudreau, 2008). Terapis Wicara (Speech Language Pathologist/ $S L P)$ memiliki peranan penting dalam aspek kemampuan phonological awareness. Peran terapis wicara yang pertama adalah memberikan pemahaman kepada anggota tim pemeriksaan dan penanganan mengenai pengetahuan tentang phonological awareness. Peran kedua adalah membagikan langkahlangkah pemeriksaan dan hasil pemeriksaan, ketiga adalah menyertai guru dalam upaya intervensi phonological awareness sesuai kurikulum. Keempat sebagai anggota tim dalam intervensi kemampuan membaca anak (Schuele \& Boudreau, 2008).

Phonological awareness memiliki tahapan kemampuan mulai dari sederhana (tidak kompleks) menuju ke aktifitas yang lebih kompleks. Kemampuan phonological awaraness dimulai dari tiga kemampuan yang lebih sederhana. Aktifitas phonological awareness yang dari yang paling sederhana menurut (Schuele \& Boudreau, 2008) antara lain: Words into syllable, Rhyme, dan Alliteration: Initial and final sounds sorts. 
Aktifitas phonological awareness yang lebih kompleks dari yang paling sederhana menurut (Schuele \& Boudreau, 2008) dimulai dari Onset-rhyme segmentation, Segment initial and final sound, Blend sounds into words, Segment words into sounds, dan Delete manipulate phonemes.

Hogan et al (2005) menjelaskan bahwa pemeriksaan phonological awareness memberikan gambaran kemampuan membaca pada masa Taman Kanak-kanak (TK) memiliki korelasi dengan kemampuan membaca anak pada saat berada pada kelas 2 Sekolah Dasar (SD). Penjelasan ini memperkuat bahwa kemampuan phonological awareness dapat dijadikan indikator atau prediktor awal kemampuan membaca anak. Hal ini sangat relevan dengan teori Pennington (2009) yang menjelaskan bahwa kemampuan phonological awareness merupakan komponen yang berkaitan dengan proses decoding. Hal ini diperkuat pendapat Cabbage et al (2018) yang menjelaskan bahwa anak dengan disleksia memiliki permasalahan pada aspek phonological awaraness.

\section{KESIMPULAN DAN SARAN}

Kesimpulan dari penelitian ini terdapat lima subtes yang bisa digunakan untuk skrining kemampuan phonological awareness usia pra-sekolah yakni Rhyme, Syllable Blending, Initial Phoneme Identification, Medial Phoneme Identification, dan Final Phoneme Identification, hasil analisis validitas internal dengan uji Spearman Rank menunjukkan bahwa korelasi antar subtes memiliki korelasi, hasil uji reliabilitas dengan uji Alpha Cronbach menunjukkan bahwa setiap subtes dinyatakan reliabel, dan penelitian ini mampu mengidentifikasi

phonological awareness anak serta menemukan ukuran rerata dan standar deviasi untuk untuk semua subtes. Hasil penelitian menemukan bahwa kebutuhan untuk melakukan penelitian yang bertujuan untuk menemukan alat ukur terstandarisasi terutama untuk pemeriksaan kemampuan phonological awareness sangat diperlukan. Perlu adanya penelitian lanjutan yang menambah ruang lingkup penelitian menjadi lebih luas agar lebih mudah dalam menggeneralisasikan hasil penelitian.

\section{DAFTAR RUJUKAN}

Cabbage, K.L., Farquharson, K.F., Seigel, J.I., Zuk, J., \& Hogan, T.P. 2018. Exploring between dyslexia and speech sound production deficits. Language, Speech, and Hearing Services in Schools. 49 (4), pp. 774786.

Ceron, M.I., Gubiani, M.B., Oliveira, C.R., Gubiani, M.B., \& KeskeSoares, M. 2017. Prevalence of phonological disorders and phonological processes in typical and atypical phonological development. CoDAS. Vol.29 (3):e20150306. Doi: 10.1590/2317-1782/20172015306.

Harrison L.J. \& McLeod, S. 2010. Risk and protective factors associated with speech and language impairment in a nationally representative sample of 4- to 5year-old children. Journal of Speech, Language, and Hearing Research. 53, pp 508-529.

Haynes W.O. \& Pindzola, R.H. 1998. Diagnosis and evaluation in speech 
pathology. ( $\left.5^{\text {th. }} \cdot \mathrm{Ed}\right)$. Boston: Allyn and Bacon

Longo, I.A, Tupinelli, G.G., Hermogenes, C., Ferreira, L.V., \& MoliniAvejonas, D.R. 2017. Prevalence of speech and language disorders in children in the western region of Sao Paulo. CoDAS. Vol.29 (6): e20160036. doi: 10.1590/2317$1782 / 20172016036$.

McLeod, S. \& Verdon, S. 2014. A review of 30 speech assessments in 19 languages other than English. American Journal of SpeechLanguage Pathology. 23, pp.708723.

Pennington, B.F. 2009. Diagnosing learning disorders: A neuropsychological framework. New York, NY: The Guilford Publication, Inc.

Schuele, C.M. \& Boudreau, D. 2008. Phonological awareness intervention: Beyond the basics. Language, Speech, and Hearing Services in Schools. 39 (1), pp.3-20.

Topbas,, S. 2006. Does the speech of Turkish-speaking phonologically disordered children differ from that of children speaking other languages? Clin Linguist Phon.Vol.20 (7-8): 509-22 